\title{
Morphological and Phylogenetic Appraisal of Novel and Extant Taxa of Stictidaceae from Northern Thailand
}

\author{
De-Ping Wei ${ }^{1,2,3,4}$, Dhanushka N. Wanasinghe ${ }^{1,5,6}$ (D) Eleni Gentekaki ${ }^{2,7}$, Vinodhini Thiyagaraja ${ }^{2,3,4}$, \\ Saisamorn Lumyong $8,9,10$ and Kevin D. Hyde 1,2,8,11,*
}

1 CAS Key Laboratory for Plant Diversity and Biogeography of East Asia, Kunming Institute of Botany, Chinese Academy of Sciences, Kunming 650201, China; wei_deping@cmu.ac.th (D.-P.W.); dnadeeshan@gmail.com (D.N.W.)

2 Center of Excellence in Fungal Research, Mae Fah Luang University, Chiang Rai 57100, Thailand; gentekaki.ele@mfu.ac.th (E.G.); vino.thiyagaraja@gmail.com (V.T.)

3 Department of Entomology and Plant Pathology, Faculty of Agriculture, Chiang Mai University, Chiang Mai 50200, Thailand

4 Mushroom Research Foundation, 128 M.3 Ban Pa Deng T. Pa Pae, A. Mae Taeng, Chiang Mai 50150, Thailand

5 World Agroforestry Centre, East and Central Asia, Kunming 650201, China

6 Centre for Mountain Futures, Kunming Institute of Botany, Kunming 650201, China

7 School of Science, Mae Fah Luang University, Chiang Rai 57100, Thailand

8 Research Center of Microbial Diversity and Sustainable Utilization, Chiang Mai University, Chiang Mai 50200, Thailand; scboi009@chiangmai.ac.th

9 Department of Biology, Faculty of Science, CHiang Mai University, Chiang Mai 50200, Thailand

10 Academy of Science, The Royal Society of Thailand, Bangkok 10300, Thailand

11 Innovative Institute of Plant Health, Zhongkai University of Agriculture and Engineering, Haizhu District, Guangzhou 510225, China

Citation: Wei, D.-P.; Wanasinghe, D.N.; Gentekaki, E.; Thiyagaraja, V.; Lumyong, S.; Hyde, K.D.

Morphological and Phylogenetic Appraisal of Novel and Extant Taxa of Stictidaceae from Northern Thailand. J. Fungi 2021, 7, 880. https://doi.org/10.3390/jof7100880

Academic Editor: Pradeep K. Divakar

Received: 24 August 2021

Accepted: 12 October 2021

Published: 19 October 2021

Publisher's Note: MDPI stays neutral with regard to jurisdictional claims in published maps and institutional affiliations.

Copyright: (c) 2021 by the authors. Licensee MDPI, Basel, Switzerland. This article is an open access article distributed under the terms and conditions of the Creative Commons Attribution (CC BY) license (https:/ / creativecommons.org/licenses/by/ $4.0 /)$.
* Correspondence: kdhyde3@gmail.com

\begin{abstract}
Stictidaceae comprises taxa with diverse lifestyles. Many species in this family are drought resistant and important for studying fungal adaptation and evolution. Stictidaceae comprises 32 genera, but many of them have been neglected for decades due to the lack of field collections and molecular data. In this study, we introduce a new species Fitzroyomyces hyaloseptisporus and a new combination Fitzroyomyces pandanicola. We also provide additional morphological and molecular data for Ostropomyces pruinosellus and O. thailandicus based on new collections isolated from an unidentified woody dicotyledonous host in Chiang Rai, Thailand. Taxonomic conclusions are made with the aid of morphological evidence and phylogenetic analysis of combined LSU, ITS and mtSSU sequence data. Characteristics such as the shape and septation of ascospores and conidia as well as lifestyles among genera of Stictidaceae are discussed.
\end{abstract}

Keywords: lichenization; new species; non-lichenized fungi; Ostropales; phylogeny; taxonomy

\section{Introduction}

Nannfeldt [1] established Ostropales to accommodate Ostropaceae, which was later synonymized under Stictidaceae [2]. The taxonomic position of Ostropales is within Ostropomycetidae (Lecanoromycetes and Ascomycota), which was assigned based on multigene phylogenetic analyses [3]. The outlines of Ostropales have been revised in several studies, and the number of families in the order has been subject to multiple changes over time [4-7]. Previously, 14 families had been included in Ostropales, namely, Coenogoniaceae, Gomphillaceae (syn. Solorinellaceae), Graphidaceae, Gyalectaceae, Odontotremataceae, Phaneromycetaceae, Phlyctidaceae, Trichotheliaceae (syn. Myeloconidaceae and Porinaceae), Protothelenellaceae (syn. Thrombiaceae), Sagiolechiaceae, Spirographaceae, Stictidaceae, Thelenellaceae and Thelotremataceae [2,4-9]. However, multigene phylogenies have ultimately resulted in the transfer of most families into different orders, such as Baeomycetales, Thellenellales, Graphidales and Gyalectales. Presently, Stictidaceae is the only family assigned to Ostropales [10]. 
Stictidaceae was introduced based on Stictis Pers, a saprobic genus, which is characterized by apothecioid ascomata, cylindrical asci and filiform ascospores [11,12]. Subsequently, researchers extended the membership of this family to include both morphologically and phylogenetically related genera [13-19]. The generic composition of Stictidaceae has been outlined by listing the genera name, but it lacks detailed annotations [4-7]. Thiyagaraja et al. [20] introduced the novel genus Ostropomyces and accepted 32 genera following the previous outline. Molecular data are lacking for Biostictis, Conotremopsis, Delpontia, Dendroseptoria, Karstenia, Lillicoa, Nanostictis, Propoliopsis, Stictophacidium and Topelia. The remaining 22 genera, including Absconditella, Acarosporina, Carestiella, Cryptodiscus, Cyanodermella, Eriospora, Fitzroyomyces, Geisleria, Glomerobolus, Hormodochis, Ingvariella, Neofitzroyomyces, Neostictis, Ostropa, Ostropomyces, Phacidiella, Robergea, Schizoxylon, Sphaeropezia, Stictis, Trinathotrema and Xyloschistes, have been confirmed as members of Stictidaceae by phylogenetic methods. Thelopsis historically has been assigned to Stictidaceae, however, recent phylogenetic analyses of combined LSU, mtSSU and RPB2 sequences have placed this genus outside this family, with the type species placing within Gyalecta (Gyalectaceae) [21]. Stictidaceae currently comprises 32 genera, including 19 sexual (in orange area, Figure 1), five asexual genera (in purple area) and seven genera for which both morphs have been observed (in blue area). Uniquely within Stictidaceae, Glomerobolus (in green area), a monotypic genus, reproduces via discharging a sticky propagule on fresh substrates rather than by producing sexual or asexual spores $[19,22]$. Molecular analyses have contributed substantially towards elucidating the natural classification of Stictidaceae [2,20]. Studies have attempted to ascertain phylogenetic relationships within and among species of Stictidaceae using different sequence datasets, such as individual SSU [12] and LSU [15-17,23,24] genes, as well as LSU-mtSSU-RPB2 [2] and LSU-ITS-mtSSU combined matrices [25-29]. However, inferring robust intergeneric relationships has been challenging given the limited sampling of Stictidaceae species.

Sexual morphs have been described for 26 genera in Stictidaceae. Members of this family typically develop apothecioid ascomata, except for Geisleria and Ostropomyces, where both possess perithecioid ascomata [18,20]. Most genera of Stictidaceae have cylindrical to clavate 8-spored asci. Nonetheless, the number of ascospores per ascus differs among genera (Figure 1). For example, Xyloschistes and Ingvariella are 1-2-spored [30], and Trinathotrema is 4-8-spored [31], while Carestiella, Schizoxylon and Stictis contain poly-spored species [13]. Deviation from 8-spored asci could have resulted from the abortion or disarticulation of primary ascospores [13]. Significant variation also exists among Stictidaceae genera regarding ascospore characteristics that might be informative in generic delimitation. The elongated clavate, long-cylindrical to filiform and multiseptate ( $>3$-septate) ascospores can be observed in Absconditella [32], Cryptodiscus [13,33], Conotremopsis [34], Karstenia [13], Lillicoa [35], Nanostictis [13], Ostropa [13], Robergea [13], Acarosporina [13], Biostictis [35], Cyanodermella [15], Fitzroyomyce [36,37], Neostictis [36], Ostropomyces [20], Propoliopsis [13], Schizoxylon [13] and Stictis [13] (Figure 1). The latter nine genera contain species whose ascospores can disarticulate into simple to septate part-spores or irregular fragments. The fusiform, oblong, ellipsoidal to short clavate and few-celled (0-3-septate) ascospores are observed in Absconditella [38,39], Biostictis [35], Cryptodiscus [40], Geisleria [18], Sphaeropezia [41,42], Stictis [13] and Stictophacidium [13]. The oblong, ellipsoidal, obovoid to cylindrical and submuriform ascospores are present in Delpontia [13], Topelia [43] and Trinathotrema [44,45]. The oblong and muriform ascospores have been noted in Ingvariella [46] and Xyloschistes [30,47].

Asexual morphs have been observed in 12 genera within Stictidaceae. In most cases, their conidiomata are pycnidial, with the exception of Biostictis (with hyphomycetous sporulation structures) [35] and Dendroseptoria (with sporodochial fruiting bodies) [48]. Four modes of conidiogenesis have been observed in this family, including blastic-phialidic (i.e., Dendroseptoria [48], Neofitzroyomyces [23], Phacidiella [23,49], Fitzroyomyce [50], Cyanodermella [51] and Stictis [52]), blastic-sympodial (i.e., Eriospora [24], Biostictis [35] and Acarosporina [53]), blastic-retrogressive (i.e., Ostropomyces [20] and Schizoxylon [53]) and 
thallic-arthric (i.e., Hormodochis [17] and Schizoxylon [53]). Stictidaceae formed aseptate, one-celled to multiseptate, ellipsoidal to long cylindrical and occasionally tetraradiate conidia (see Figure 1).

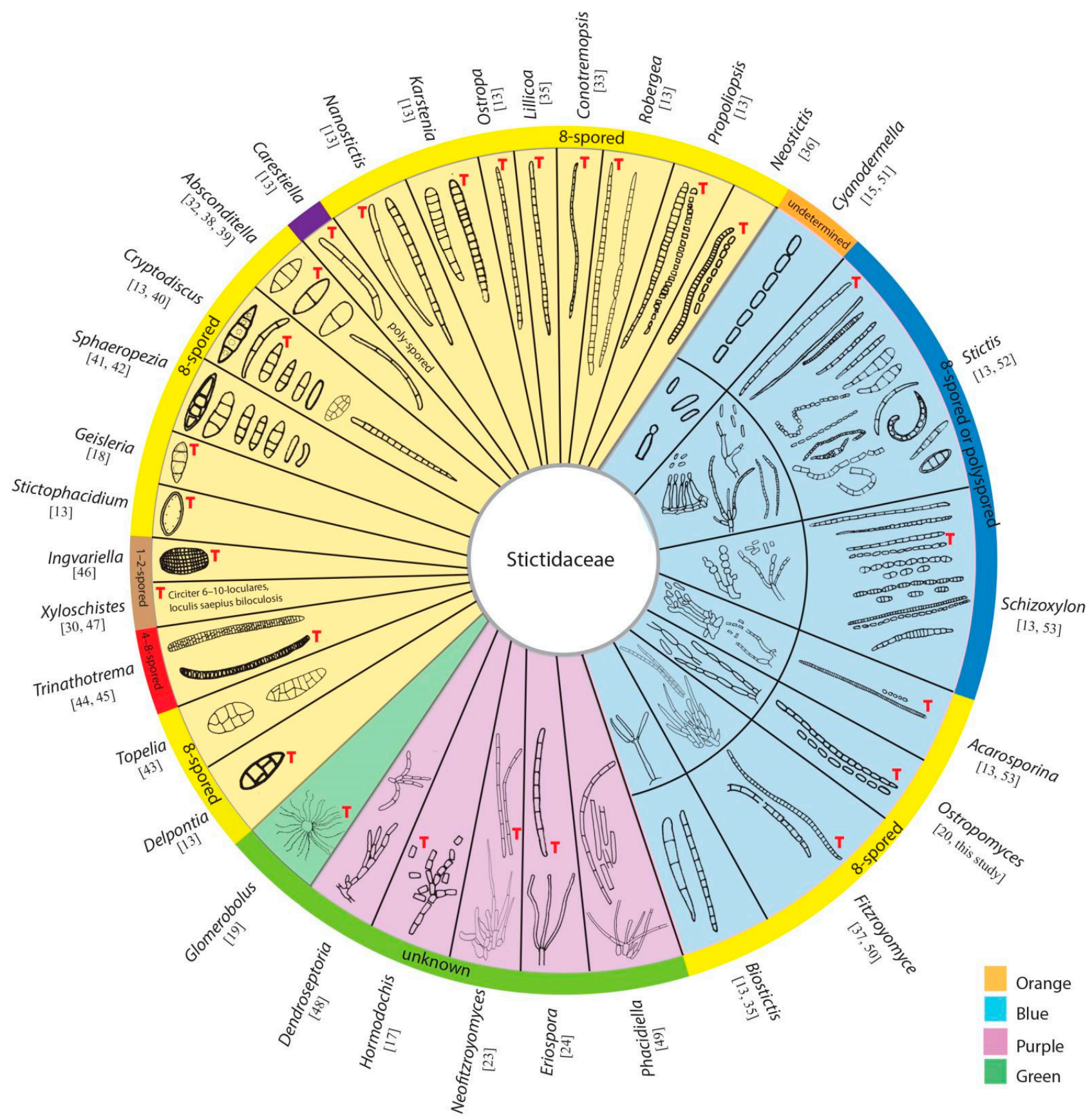

Figure 1. Morphology of ascospores, conidia and conidiogenesis of 32 genera in Stictidaceae. The orange area contains genera known only from sexual morphs; the area in purple comprises genera that were established based only on asexual morphs; and the area in blue encompasses genera that were described from both sexual and asexual morphs, while the area in green consists of a single genus, which reproduces via sticky propagules rather than sexual or asexual spores. The number of ascospores per ascus for each genus is noted in the outermost circle. The ascospores and conidia indicated with the red letters " $\mathrm{T}$ " were redrawn from the type species. The original references of these characters are cited for each genus.

Stictidaceae species commonly occur on bark, leaves, stems and wood of various plant hosts in terrestrial habitats [25] and have broad geographic distribution in Africa, Asia, Europe and North America [13]. This family contains a broad diversity of lifestyles, ranging 
from saprobes, pathogens and endophytes to lichens. Lichenicolous species have been recorded in Cryptodiscus, Nanostictis and Sphaeropezia [33,42,54], while Schizoxylon albescens, Stictis confusa and Stictis populorum show optionally lichenized lifestyles depending on the associated substrates $[55,56]$. Thus, Stictidaceae played an important role in understanding how fungi can adapt to various successional substrates during habitat succession by switching lifestyle [55].

In this study, we aim to clarify the taxonomic placement of new species (Fitzroyomyces hyaloseptisporus sp. nov. and Fitzroyomyces pandanicola comb. nov) and two previously described species (Ostropomyces pruinosellus and O. thailandicus) by using morphological and multigene-based phylogenetic analyses. To provide an identification scheme for all genera of Stictidaceae, the diversity of ascospore/conidia morphology and the mode of conidial development is summarized. Descriptions of sexual and asexual morphs of Stictidaceae are refined to keep abreast of current literature. The lifestyles of genera in Stictidaceae are mapped on the phylogenetic tree in order to visualize these features in a phylogenetic context and to explore the transition of nutrition modes in Stictidaceae.

\section{Materials and Methods}

\subsection{Sample Collections and Isolation}

Specimens were collected from an unidentified woody dicotyledonous plant in northern Thailand. Pure cultures were obtained via single spore isolation as outlined in Senanayake et al. [57]. The obtained cultures were deposited in Mae Fah Luang University culture collection (MFLUCC), Chiang Rai, Thailand, and herbarium specimens were deposited in Mae Fah Luang University Herbarium (Herb. MFLU). The Faces of Fungi numbers were obtained following Jayasiri et al. [58], and species names were registered in Index Fungorum (2021).

\subsection{Morphological Studies}

Specimens were examined with a Motic SMZ 168 stereomicroscope. Hand sections of the ascomata and conidiomata were mounted in water for microscopic studies and photomicrography. A Congo red solution was used to observe asci and paraphyses. The key structures such as ascomata, exciple, paraphyses, asci, ascospores, conidiogenous cells and conidia were observed by using a Nikon ECLIPSE 80i compound microscope, and they were photographed with a DS-Ri2 camera attached to the compound microscope. The measurements were taken with the Tarosoft (R) Image Frame Work program, while images used for figures were processed with Adobe Photoshop CS3 (Version 15.0.0, Adobe ${ }^{\circledR}$, San Jose, CA, USA).Extended version 10.0 (Adobe Systems, San Jose, CA, USA).

\subsection{DNA Extraction, PCR Amplification and Sequencing}

Genomic DNA was extracted separately from both fresh fungal mycelia growing on potato dextrose agar (PDA) media and fruiting bodies using Biospin Fungus Genomic DNA Extraction Kit (BioFlux ${ }^{\circledR}$, Hangzhou, China) following the protocol of the manufacturer. Polymerase chain reaction (PCR) was carried out for three partial gene fragments including large subunit ribosomal rRNA (LSU), internal transcribed spacers (ITS) and mitochondrial small subunit ribosomal rRNA (mtSSU) with primers LR0R/LR5 [59], ITS5/ITS4 [60] and mrSSU1/mrSSU3R [61], respectively. Amplification reactions were performed in $25 \mu \mathrm{L}$ of PCR mixtures containing $8.5 \mu \mathrm{L}$ of ddH2O, $12.5 \mu \mathrm{L} 2 \times$ PCR Master Mix (Bioteke Corporation, Beijing, China), $2 \mu \mathrm{L}$ of DNA template and $1 \mu \mathrm{L}$ of each primer. PCR amplifications of LSU and ITS genes were performed as described by Wanasinghe et al. [33], while mtSSU gene was amplified following Zoller et al. [61]. Amplified PCR products were sequenced in Tsingke (Kunming, China). Sequences generated in this study were deposited in GenBank, and accession numbers were obtained (see Table 1). 
Table 1. GenBank accession numbers of the taxa used in the phylogenetic analyses in this study.

\begin{tabular}{|c|c|c|c|c|}
\hline Species & Strain Number & LSU & ITS & mtSSU \\
\hline Absconditella sphagnorum & M24 & EU940095 & - & EU940247 \\
\hline Absconditella sphagnorum & Palice 3820 & AY300825 & - & AY300873 \\
\hline Acarosporina microspora & AFTOL-ID 78 & AY584643 & DQ782834 & AY584612 \\
\hline Carestiella socia & GG2410 & - & AY661687 & AY661677 \\
\hline Carestiella socia & GG2437a & - & AY661682 & AY661678 \\
\hline Carestiella socia & Wedin 7194 & - & - & JX266155 \\
\hline Chromatochlamys muscorum & Palice 8634 & AY607731 & - & AY607743 \\
\hline Cryptodiscus cladoniicola & RP160 & KY661653 & KY661620 & KY661675 \\
\hline Cryptodiscus cladoniicola & RP159 & KY661652 & KY661619 & KY661674 \\
\hline Cryptodiscus epicladonia & $\mathrm{RP} 208^{\mathrm{T}}$ & - & KY661628 & KY661680 \\
\hline Cryptodiscus foveolaris & EB155 & - & FJ904673 & FJ904695 \\
\hline Cryptodiscus gloeocapsa & EB93 & - & FJ904674 & FJ904696 \\
\hline Cryptodiscus incolor & EB164 & - & FJ904675 & FJ904697 \\
\hline Cryptodiscus muriformis & H.B. 6773 & MG281963 & MG281963 & MG281973 \\
\hline Cryptodiscus pallidus & EB173 & - & FJ904680 & FJ904702 \\
\hline Cryptodiscus pallidus & EB152 & - & FJ904679 & FJ904701 \\
\hline Cryptodiscus pini & EB181 & - & FJ904684 & FJ904706 \\
\hline Cryptodiscus pini & EB178 & - & FJ904683 & FJ904705 \\
\hline Cryptodiscus tabularum & CO205 & - & FJ904690 & FJ904712 \\
\hline Cryptodiscus tabularum & EB169 & - & FJ904689 & FJ904711 \\
\hline Cyanodermella asteris & 03HOR06-2-4 ${ }^{\mathrm{T}}$ & & KT758843 & KT758843 \\
\hline Cyanodermella banksiae & CPC:32105 ${ }^{\mathrm{T}}$ & NG_064548 & NR_159835 & - \\
\hline Cyanodermella oleoligni & CBS $140345^{\mathrm{T}}$ & NG_058973 & NR_153930 & KX999144 \\
\hline Cyanodermella viridula & EB146 & HM244763 & - & HM244739 \\
\hline Eriospora leucostoma & CPC:35594 & MT223890 & MT223795 & - \\
\hline Fitzroyomyces cyperacearum & MFLU 18-0695b & MK499361 & MK499349 & - \\
\hline Fitzroyomyces cyperacearum & CBS $143170^{\mathrm{T}}$ & NG_058513 & NR_156387 & - \\
\hline $\begin{array}{l}\text { Fitzroyomyces } \\
\text { hyaloseptisporus }\end{array}$ & $\underset{T}{\operatorname{MFLUCC}} 21-0111$ & MZ868921 & MZ868916 & MZ868911 \\
\hline Stictis pandanicola & $\begin{array}{c}\text { HKAS } 96206^{\mathrm{T}} \\
\text { Caceres and }\end{array}$ & MH260319 & MH275085 & - \\
\hline Geisleria sychnogonoides & $\begin{array}{l}\text { Aptroot } 13560 \\
\text { (ABL) }\end{array}$ & KC689752 & - & KC689751 \\
\hline Geisleria sychnogonoides & 70627 & KF220304 & - & KF220306 \\
\hline Glomerobolus gelineus & JK 5584C & DQ247798 & - & DQ247783 \\
\hline Glomerobolus gelineus & AFTOL-ID 1349 & - & DQ247782 & DQ247784 \\
\hline Hormodochis aggregata & CPC $30683^{\mathrm{T}}$ & MN317280 & NR_166307 & - \\
\hline Hormodochis melanochlora & CBS $138861^{\mathrm{T}}$ & NG_070381 & NR_165507 & - \\
\hline Ingvariella bispora & MALich 15288 & HQ659184 & - & HQ659173 \\
\hline Ingvariella bispora & BCNLich 17183 & HQ659185 & - & HQ659174 \\
\hline Neofitzroyomyces nerii & CBS $145088^{\mathrm{T}}$ & NG_068278 & NR_161144 & - \\
\hline Neostictis nigricans & MFLU $18-1380^{\mathrm{T}}$ & MT214610 & MT310654 & - \\
\hline Orceolina kerguelensis & Søchting 9398(C) & AY212830 & AY212814 & AY212853 \\
\hline Ostropa barbara & SW071 (S) & HM244773 & HM244773 & HM244752 \\
\hline Ostropa barbara & S F302817 & MG281965 & MG281965 & MG281974 \\
\hline Ostropomyces pruinosellus & MFLU $20-0538^{\mathrm{T}}$ & MW400966 & MW400964 & \\
\hline Ostropomyces pruinosellus & MFLUCC 21-0112 & MZ868917 & MZ868912 & MZ868907 \\
\hline Ostropomyces pruinosellus & MFLU 21-0115 & MZ868918 & MZ868913 & MZ868908 \\
\hline Ostropomyces thailandicus & MFLU 20-0539 T & MW397060 & MW400967 & - \\
\hline Ostropomyces thailandicus & MFLUCC 21-0113 & MZ868919 & MZ868914 & MZ868909 \\
\hline Ostropomyces thailandicus & MFLU 21-0116 & MZ868920 & MZ868915 & MZ868910 \\
\hline Phacidiella alsophilae & CPC: $37041^{\mathrm{T}}$ & MT373344 & MT373361 & - \\
\hline Placopsis perrugosa & KS137 & KU844613 & KU844737 & KU844549 \\
\hline
\end{tabular}


Table 1. Cont.

\begin{tabular}{ccccc}
\hline Species & Strain Number & LSU & ITS & mtSSU \\
\hline Robergea cubicularis & G.M. 2017-10-12.1 & MN833317 & MN833317 & - \\
Robergea cubicularis & G.M. 2013-05-09.1 & KY611899 & KY611899 & - \\
Schizoxylon albescens & GG2443a & AY661690 & AY661690 & AY661681 \\
Schizoxylon berkeleyanum & S F209682 & MG281966 & MG281966 & MG281975 \\
Schizoxylon gilenstamii & S F300892 & MG281968 & MG281968 & MG281977 \\
Sphaeropezia leucocheila & PDD:98299 T & MK547099 & MK547090 & MK547101 \\
Sphaeropezia lyckselensis & EB-2012a & JX266158 & - & JX266156 \\
Sphaeropezia mycoblasti & EB-2012b & JX266159 & - & JX266157 \\
Sphaeropezia shangrilaensis & MFLU 20-0537 T & MW400965 & MW400955 & MW400962 \\
Stictis anhuiensis & HOU1233M & KX447623 & - & KX447625 \\
Stictis anhuiensis & HOU1233 & KX447622 & - & KX447624 \\
Stictis brunnescens & GG2359 & AY661688 & AY661688 & AY661679 \\
Stictis confusa & Wedin 7070 & - & NR_121318 & DQ401141 \\
Stictis mollis & MW7200 & AY527313 & AY527313 & - \\
Stictis mollis & GG2445a & AY527318 & AY527318 & - \\
Stictis populorum & GG2610a & AY527327 & AY527327 & AY527356 \\
Stictis populorum & GG2618 T & AY527331 & AY527331 & AY527360 \\
Stictis radiata & GG2449a & AY527308 & AY527308 & - \\
Stictis radiata & MW6493 & AY527309 & AY527309 & - \\
Stictis urceolatum & LT21500 & AY661686 & AY661686 & AY661676 \\
Thelenella antarctica & Lumbsch 19006a (F) & AY607739 & - & KU844758 \\
Trapelia placodioides & KS163 & KU844623 & - & AY607749 \\
Trinathotrema stictideum & F:Luecking 17541b & - & - & KU844568 \\
Trinathotrema stictideum & F:Luecking 28093 & GFU380288 \\
Xyloschistes platytropa & AFTO-ID 4891 & KJ766680 & GU380287 \\
\hline
\end{tabular}

The newly generated sequences are in bold font. The type strains are indicated with the symbol " $\mathrm{T}$ ".

\subsection{Sequence Alignment and Phylogenetic Analyses}

Raw sequences generated in this study were assembled with Sequencing Project Management (SeqMan) [62]. Megablast search using the newly generated sequences as queries was performed to check for contamination and to reveal closely related taxa in the GenBank nucleotide database. The available taxa representing genera in Stictidaceae are listed in Table 1. Each gene matrix was independently aligned with MAFFT (http: // mafft.cbrc.jp/alignment/server/, accessed on 31 July 2021) [63]. Uninformative gaps and ambiguous regions were removed using Trimal available on the Phylemon 2.0 online platform [64]. Trimmed alignments were combined with Sequence Matrix v. 1.7.8 [65]. The combined alignment was used for maximum likelihood (ML) and Bayesian inference (BI) analyses.

Maximum likelihood analysis was performed using RAxML-HPC2 on XSEDE (8.2.10) in CIPRES Science Gateway V. 3.3 [66] by employing default parameters but with the following adjustments: Bootstrap iterations were set to 1000, and substitution model was set to GTR+GAMMA+I. The optimal nucleotide substitution models used for Bayesian analysis were independently selected for each locus under Akaike information criterion (AIC). Bayesian analysis was performed with MrBayes 3.2.7a in CIPRES Science Gateway v. 3.3 [67] in order to infer posterior probabilities (PP) [68,69] with Markov Chain Monte Carlo sampling (MCMC). Six simultaneous Markov chains were run for 2,000,000 generations, and trees were sampled every 1000 generations, resulting in 2000 trees. The first $25 \%$ of trees, representing the burn-in phase of the analyses, were discarded, while the remaining $75 \%$ of trees were used to calculate PP in the majority rule consensus tree. 
Phylograms were visualized with FigTree v1.4.0 program [70] and edited in Microsoft power point (2016) and Adobe Illustrator ${ }^{\circledR}$ CS3 (Version 15.0.0, Adobe ${ }^{\circledR}$, San Jose, CA, USA). The final combined alignment was submitted to TreeBASE with submission number 28693 (http:/ / purl.org/phylo/treebase/phylows/study/TB2:S28693, accessed on 31 July 2021).

\section{Results}

\subsection{Phylogenetic Analysis}

Maximum likelihood phylogenetic analysis was conducted using combined LSU, ITS and mtSSU sequence data of 70 representative taxa of Stictidaceae, two species of Thelenellaceae and three species of Trapeliaceae. The tree is artificially rooted to Orceolina kerguelensis, Placopsis perrugosa and Trapelia placodioides in Trapeliaceae, following Baloch et al. [7]. Of the 32 genera within Stictidaceae, molecular data are available for 22, 17 of which contain the type species. Thus, the sequences from all 22 genera are used in the phylogenetic analysis herein. Alignment comprised 2140 characters, including gaps (LSU: 841; ITS: 569; mtSSU: 730), of which 1001 characters were constant, 203 variable characters were parsimony-uninformative and $936(43 \%)$ characters were parsimony-informative. The ML analysis of the combined dataset yielded a best scoring tree with a final ML optimization likelihood value of $-26,748.800570$. The alignment had 1332 distinct alignment patterns, with $30.23 \%$ completely undetermined characters and gaps.

In the phylogenetic tree (Figure 2), Cryptodiscus, Cyanodermella, Fitzroyomyces, Ostropomyces and Sphaeropezia are monophyletic, while Schizoxylon and Stictis are polyphyletic. Fitzroyomyces, Eriospora, Neofitzroyomyces and Phacidiella form a clade with high statistical support (100\% MLBS/1.00 PP). The asexual morphs of these genera commonly occur on plant leaves, whereas the sexual morph of Fitzroyomyces has been found on dead woody stems $[23,24,49,50]$. The lichenized genera Geisleria and Absconditella formed sister clades with high support (92\% MLBS/0.99 PP). Xyloschistes platytropa, a saprobe [30], is sister to Ingvariella bispora, a lichen [46], with maximum support (100\% MLBS/1.00 PP). Our strain MFLUCC 21-0111 together with F. cyperacearum and F. pandanicola formed a monophyletic clade with maximum support (100\% MLBS/1.00 PP). The new strains MFLUCC 21-0112 (from mycelia) and MFLU 21-0115 (from fruiting bodies) clustered with Ostropomyces pruinosellus with maximum statistical support values (100\% MLBS/1.00 PP). The strains MFLUCC 21-0113 (from mycelia) and MFLU 21-0116 (from fruiting bodies) grouped with $\mathrm{O}$. thailandicus also possessed maximum support (100\% MLBS/1.00 PP).

\subsection{Taxonomy}

3.2.1. Stictidaceae Fr. (as 'Stictei'), Summa Veg. Scand., Sectio Post. (Stockholm): 345 (1849) Amend

Notes: Stictidaceae was briefly described as having apothecioid to perithecioid ascomata, unbranched paraphyses, cylindrical asci and filamentous ascospores [12,25,37]. Species in this family show high variation in ascospore shape and septation. Thus, a high diversity in characteristics emphasized the need for further revision of Stictidaceae. In this study, we amended Stictidaceae by inserting 1-spored to poly-spored asci, subglobose, oblong, fusiform, clavate, vermiform aseptate, few-celled and submuriform to muriform ascospores. We also summarize features of the asexual morphs of this family for the first time. 


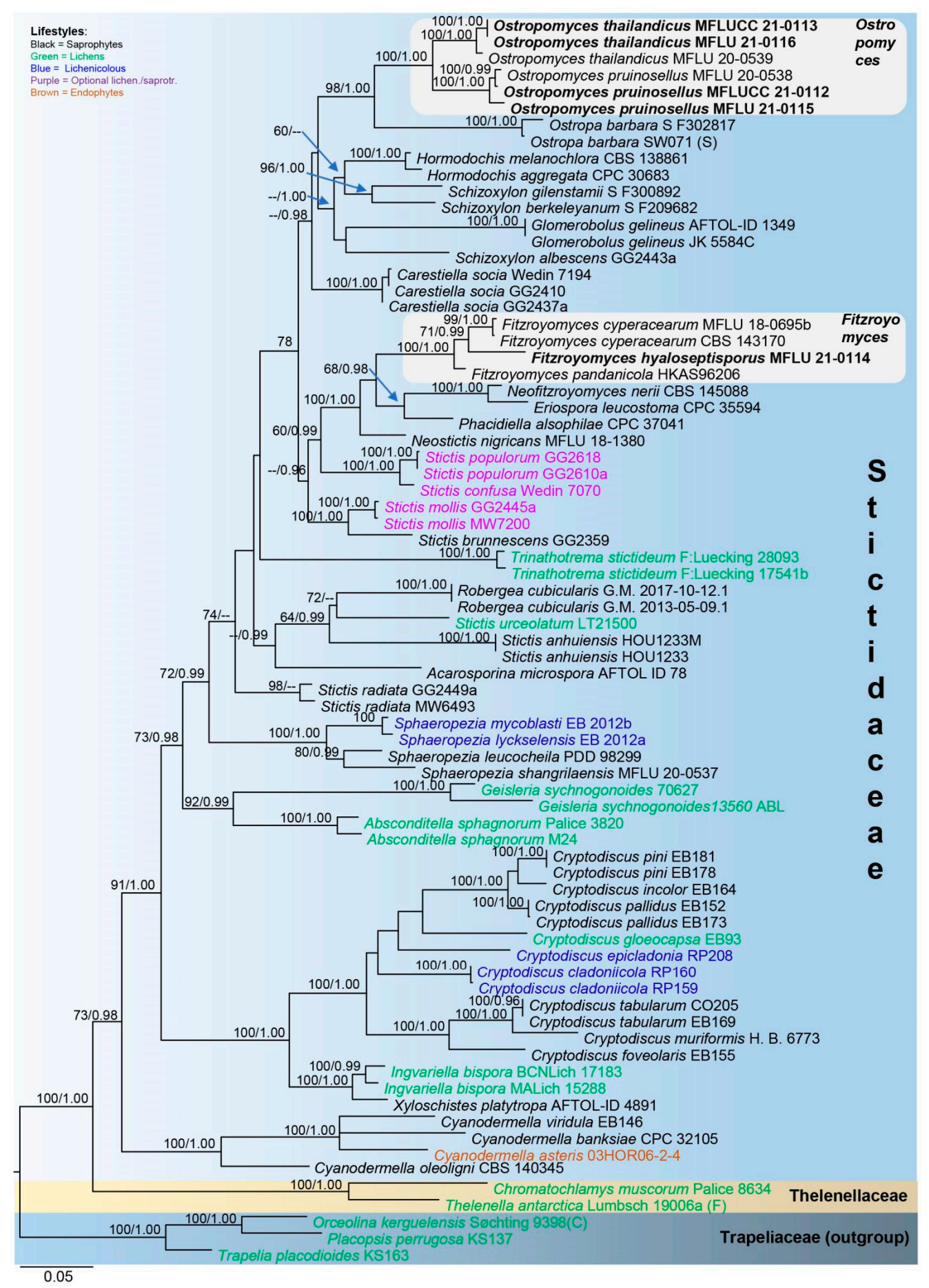

Figure 2. Phylogram generated from maximum likelihood analysis based on combined LSU, ITS and $\mathrm{mtSSU}$ sequence data. The tree was inferred from 75 taxa and 2140 sites. Maximum likelihood bootstrap support (MLBS) equal to or greater than 60\% and Bayesian posterior probabilities (PP) equal to or higher than 0.95 are placed on the nodes in this order. The newly generated sequences are indicated in bold font.

Saprotrophic, lichenized or optionally lichenized on the wood, bark, stem and leaves of various plant hosts, or are lichenicolous on other microfungi or living as parasites and endophytes of living plants. Sexual morph: Ascomata immersed or semi-immersed to superficial, perithecioid or apothecioid. They are gregarious, opening by the entire pore or transverse slit. Discs vary in color ranging from white, grey and brown to dark and are usually pruinose. Exciple typically consists of interwoven hyphae, sometimes 
contains crystalline inclusions. Periphysoids present or not. Hymenium comprising asci and paraphyses, commonly enclosed in a thick gelatinous matrix. The subhymenium is hyaline or pigmented and composed of angular cells. The paraphyses is filiform, simple or branched and sometimes apically enlarged, circinate and adhering to form an epithecium. Asci are cylindrical to clavate, 1-spored to poly-spored and usually possess thickened apex. Ascospores are typically hyaline, variable in shape and septation and span from subglobose, oblong, fusiform, clavate, vermiform, cylindrical to filiform and from aseptate, few-celled, multiseptate to muriform, breaking into part-spores or not. Asexual morph: Conidiomata are pycnidial or sporodochial and rarely hyphomycetous; they are globose to disc-shaped, hyaline, subhyaline, green and pale brown to dark. Conidiophores are hyaline to subhyaline, cylindrical, septate or aseptate and simple or branched. Conidiogenous cells are hyaline to subhyaline, subcylindrical to doliiform and usually simple, smooth-walled, enteroblastic, holoblastic or holothallic. Conidia are hyaline to dark olivaceous, doliiform, cylindrical, acicular, filiform, one-celled to multiseptated and occasionally staurosporous.

\subsubsection{Fitzroyomyces Crous, Persoonia 39: 389 (2017)}

Index Fungorum number: IF 823395, three morphological species and three species with molecular data.

Type species-Fitzroyomyces cyperacearum Crous (2017).

Notes: Fitzroyomyces was described to accommodate F. cyperacearum (=F. cyperi), the asexual morph of which was recorded from the leaves of Cyperaceae in Australia [50]. The sexual morph of F. cyperacearum has been recorded from a dead stem of Clematis subumbellata and Epilobium angustifolium in Thailand [36,37]. Fitzroyomyces is characterized by immersed and cupulate apothecia with a crystalliferous exciple and cylindric-clavate asci with a thickened apex and cylindrical-filiform, multiseptated and hyaline ascospores with one to three deep constrictions, which seemingly contribute to the fragmentation.

Fitzroyomyces hyaloseptisporus D. P. Wei and K. D. Hyde, sp. nov. Figure 3.

Index Fungorum number: IF558678; Facesoffungi number: FoF 10095.

Etymology: The specific epithet "hyaloseptisporus" refers to the fungus having hyaline and multi-septate ascospores.

Saprobic on dead stem of an unidentified climbing plant in a tropical forest. Sexual morph includes the following: Apothecia, 140-200 $\times 150-200 \mu \mathrm{m}(\overline{\mathrm{x}}=170 \times 175, n=5)$, subglobose, gregarious, immersed at first and opening by entire pore at maturity; Disc deeply cupulate, pale creamy and with white-pruinose margin. Exciple, $6-20 \mu \mathrm{m}(\overline{\mathrm{x}}=10$, $n=25)$, comprising hyaline cells of textura angularis, thin, without periphysoidal layer and with crystalliferous upper part. Hymenium is embedded in a gelatinous matrix, comprising paraphyses and asci and can easily slip away from exciple when dry. The Sub-hymenium is thin, consisting of hyaline cells of textura angularis. Epithecium is absent. Paraphyses is 1-3 $\mu \mathrm{m}(\overline{\mathrm{x}}=2, n=25)$ in the wide, hyaline, filiform, unbranched and septate and apically cohering. Asci ranged at 165-200 × 10-25 $\mu \mathrm{m}(\overline{\mathrm{x}}=180 \times 15, n=25), 8$-spored, unitunicate, cylindric-clavate and broadest at middle part, with thickened and rounded apex. Ascospores are 150-200 $\times 3.5-6 \mu \mathrm{m}(\overline{\mathrm{x}}=172 \times 5, n=25)$, hyaline and long-cylindrical, with acute ends; they are frequently multiseptate, up to 58-septa and finely guttulate when mature. They have a spiral arrangement, commonly presenting 1-3 prominent constrictions, where the entire ascospores easily break into different size of fragments. Cells of ascospores are 2-7 $\mu \mathrm{m}$ $(\bar{x}=4.5, n=30)$ long. 

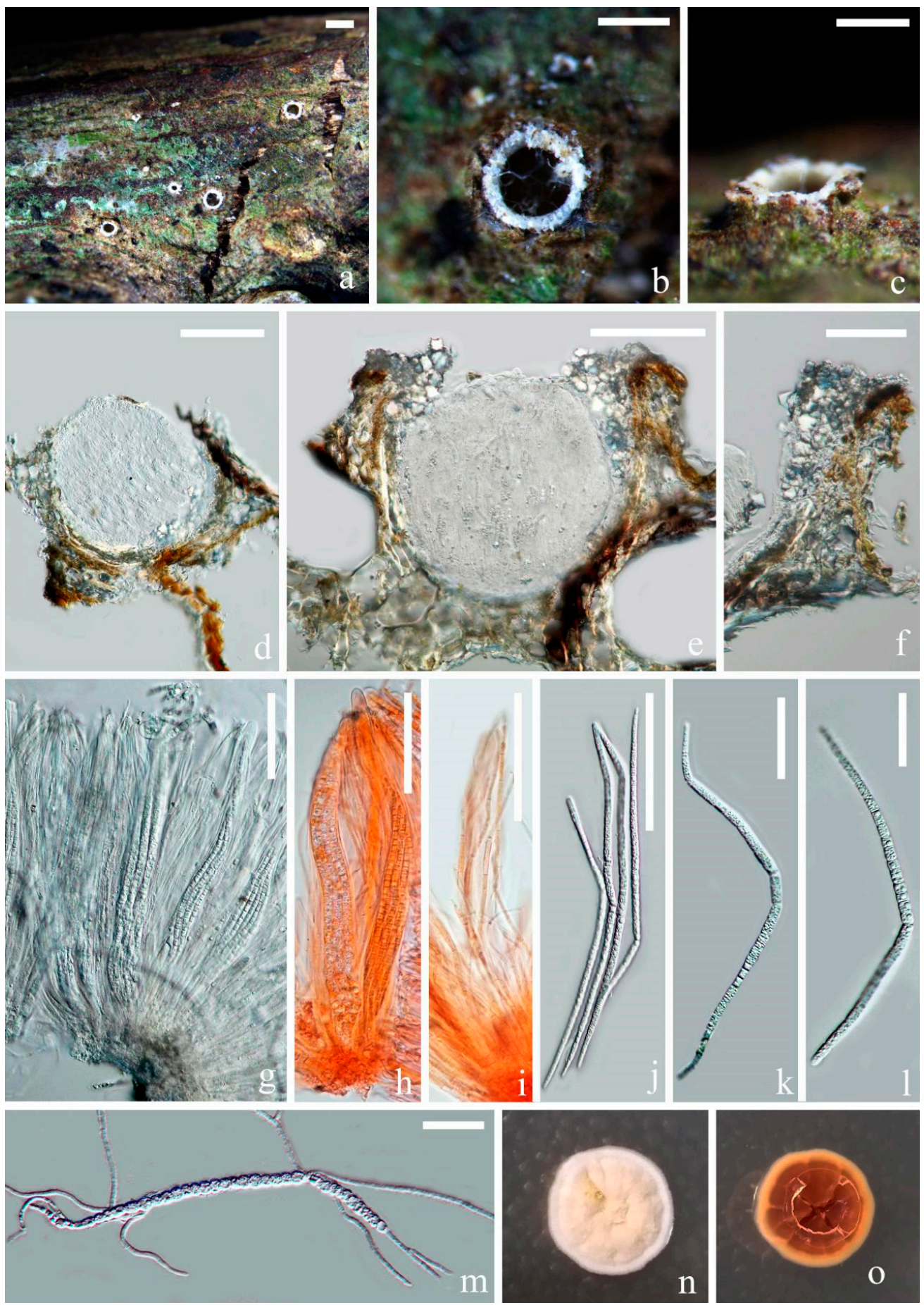

Figure 3. Fitzroyomyces hyaloseptisporus (MFLU 21-0114, holotype). (a-c) Apothecia on host; (d,e) vertical sections through apothecia; (f) excipulum; $(\mathbf{g}, \mathbf{h})$ asci; (i) paraphyses growing from subhymenium; $(\mathbf{j}-\mathbf{l})$ ascospores; $(\mathbf{m})$ germinating ascospore; $(\mathbf{n}, \mathbf{o})$ upper and lower view of culture on PDA agar after incubation for 16 days. Scale bars: $(\mathbf{a})=500 \mu \mathrm{m} ;(\mathbf{b}, \mathbf{c})=200 \mu \mathrm{m} ;(\mathbf{d}, \mathbf{e})=100 \mu \mathrm{m} ;(\mathbf{f}-\mathbf{i})=50 \mu \mathrm{m}$; $(\mathbf{j}-\mathbf{m})=30 \mu \mathrm{m} .((\mathbf{h}, \mathbf{i}))$ mounted in Congo red solution. $)$

Culture characters: Culture was established from the germinating ascospore. Colony moderately growing on PDA media, reaching $2.5 \mathrm{~cm}$ after incubation for 16 days at $28^{\circ} \mathrm{C}$. The culture was sterile, white, entire, dense, raised, radially striated, cottony and reverse reddish brown. 
Material examined: Thailand, Chiang Mai Province, Mushroom Research Center, on dead stem of an unidentified dicotyledonous climbing plant, 17 February 2019, Deping Wei, MRC13 (MFLU 21-0114, holotype); ex-type living culture MFLUCC 21-0111.

Notes: In the multigene phylogenetic tree, two strains of F. cyperacearum form a sister clade with significant support (99\% MLBS/1.00 PP). Our new species, Fitzroyomyces hyaloseptisporus (MFLU 21-0114), forms a distinct clade nested between F. cyperacearum and F. pandanicola with middle support (71\% MLBS/0.99 PP) (Figure 2). However, F. hyaloseptisporus differs from F. cyperacearum (MFLU 17-1480) in having small apothecia, different excipulum textura, septate paraphyses, larger asci and greater finely guttulate ascospores with more septations (Table 2). Fitzroyomyces hyaloseptisporus can be distinguished from F. pandanicola by its smaller apothecia, thinner excipulum with textura angularis, septate, wider paraphyses and smaller guttulate ascospore with more septations (Table 2). The sequence comparisons show $37 \mathrm{bp}(4.3 \%)$ differences in a $844 \mathrm{bp}$ fragment of LSU and $50 \mathrm{bp}(6.5 \%)$ differences in a 765 fragment of ITS between Fitzroyomyces hyaloseptisporus and the type strain of $F$. cyperacearum (CBS 143170). The nucleotide differences between Fitzroyomyces hyaloseptisporus and F. pandanicola (HKAS 96206) were 32 bp (3.8\%) in LSU (837 bp) and $33 \mathrm{bp}(6.1 \%)$ in ITS (540 bp) regions. Fitzroyomyces cyperacearum is the only species that was represented by multiple strains (namely MFLU 18-0695b [37], MFLUCC 17-2072 [36] and CBS: 143170 [50]) that have low genetic diversity in the LSU region with $0.4 \%(5 / 1010 \mathrm{bp})$ difference and with $0.6 \%$ (4/595 bp) differences in the ITS region, suggesting that there is low intraspecific variation within Fitzroyomyces. Based on the guidance of Jeewon and Hyde [71], a minimum of $>1.5 \%$ nucleotide differences in the ITS regions may be indicative of a new species. Therefore, the evidence from phylogenetic analyses, morphological observation and comparison of nucleotide sequences supports the establishment of a new species.

Table 2. Morphological comparison of Fitzroyomyces species.

\begin{tabular}{|c|c|c|c|c|c|c|c|c|}
\hline Species & Strain & $\begin{array}{l}\text { Apothecia } \\
(\mu \mathrm{m})\end{array}$ & $\begin{array}{l}\text { Exciple } \\
(\mu \mathrm{m})\end{array}$ & $\begin{array}{l}\text { Paraphyses } \\
(\mu \mathrm{m})\end{array}$ & Asci $(\mu \mathrm{m})$ & $\begin{array}{c}\text { Ascospores } \\
(\mu \mathrm{m})\end{array}$ & Septation & Reference \\
\hline $\begin{array}{l}\text { F. cyper- } \\
\text { acearum }\end{array}$ & $\begin{array}{c}\text { MFLU } \\
17-1480\end{array}$ & $\begin{array}{c}201-260 \times \\
210-310\end{array}$ & $\begin{array}{c}\text { 17-70, } \\
\text { textura } \\
\text { intricata }\end{array}$ & $\begin{array}{c}1.3-3, \\
\text { aseptate }\end{array}$ & $\begin{array}{c}110-150 \times \\
10-20\end{array}$ & $\begin{array}{c}100-145 \times \\
2.5-3.5 \\
\text { eguttulate }\end{array}$ & $17-21$ & [36] \\
\hline $\begin{array}{c}F . \\
\text { hyalosep- } \\
\text { tisporus }\end{array}$ & $\begin{array}{l}\text { MFLU } \\
\text { 21-0114 }\end{array}$ & $\begin{array}{c}140-200 \times \\
150-200\end{array}$ & $\begin{array}{c}\text { 6-20, } \\
\text { textura } \\
\text { angularis }\end{array}$ & $1-3$, septate & $\begin{array}{c}165-200 \times \\
10-25\end{array}$ & $\begin{array}{l}150-200 \times \\
3.5-6, \text { finely } \\
\text { guttulate }\end{array}$ & up to 58 & this study \\
\hline $\begin{array}{l}\text { F. pandani- } \\
\quad \text { cola }\end{array}$ & $\begin{array}{l}\text { HKAS } \\
96206\end{array}$ & $\begin{array}{c}350-410 \times \\
520-650\end{array}$ & $\begin{array}{l}\text { 27-46, } \\
\text { textura epi- } \\
\text { dermoidea }\end{array}$ & $\begin{array}{c}0.8-1.1 \\
\text { aseptate }\end{array}$ & $\begin{array}{c}160-240 \times \\
7.5-23\end{array}$ & $\begin{array}{c}190-265 \times \\
4-5, \\
\text { eguttulate }\end{array}$ & up to 40 & [25] \\
\hline
\end{tabular}

Fitzroyomyces pandanicola (Tibpromma and K.D. Hyde), D. P. Wei and K.D. Hyde, comb. nov. Basionym: Stictis pandanicola Tibpromma and K.D. Hyde, 93: 78 (2018).

Index Fungorum number: IF 558679; Facesoffungi number: FoF 10096.

Notes: Stictis pandanicola was introduced by Tibpromma et al. [25] from a dead leaf of Pandanus sp. in Xishuangbanna, Yunnan Province, China. Stictis pandanicola formed a distinct clade restricted to the genus Stictis in their phylogenetic analyses [25]. Stictis is a polyphyletic genus whose natural classification remains unresolved [13]. Stictis pandanicola clustered with the extant species of Fitzroyomyces in this study and formed a distinct clade with maximum bootstrap support (100\% MLBS/1.00 PP; Figure 2). Stictis pandanicola shares similar characteristics with Fitzroyomyces such as immersed and cupulate apothecia, a crystalliferous exciple, cylindric-clavate asci with thickened apices and cylindrical-filiform, multiseptated and hyaline ascospores. Thus, S. pandanicola is transferred to Fitzroyomyces based on phylogenetic and morphological evidence. 
3.2.3. Ostropomyces Thiyagaraja, Lücking, Ertz and K.D. Hyde, in Thiyagaraja, Lücking, Ertz, Karunarathna, Wanasinghe, Lumyong and Hyde, Journal of Fungi 7(no. 105): 11 (2021)

Index Fungorum number: IF 556555, two morphological species and two species with molecular data.

Type species: Ostropomyces pruinosellus Thiyagaraja, Lücking, Ertz and K.D. Hyde (2021).

Notes: Ostropomyces was introduced by Thiyagaraja et al. [20] based on O. pruinosellus and $O$. thailandicus. Both species were discovered on the same unidentified dead stem in Chiang Mai, Thailand. In this study, the phylogenetic analyses of LSU, ITS and mtSSU combined data (Figure 2) showed that the sexual isolates (MFLUCC 21-0112 and MFLU 21-0115) clustered with O. pruinosellus, while the asexual ones (MFLUCC 21-0113 and MFLU 21-0116) grouped with $O$. thailandicus. Both our asexual and sexual isolates were collected from an unidentified climbing plant in Chiang Rai, Thailand. These species are in close association with each other and appear during the dry season (February to March in northern Thailand). It is worth mentioning that the ascomata of $O$. pruinosellus somehow differed from general perithecioid ascoma morphology in developing an exposed disc, with the hymenium being entirely encompassed by excipulum. At first glance, this kind of ascoma resembles apothecioid ascoma. Here, we provide molecular and morphological data as well as culture characteristics for O. pruinosellus and O. thailandicus. All three strains of $O$. pruinosellus grouped together and branched seperately from $O$. thailandicus in the combined dataset phylogenetic tree (Figure 2). Three strains of O. pruinosellus differed by $0.8 \%(7 / 788 \mathrm{bp})$ in LSU and $4.3 \%(23 / 528 \mathrm{bp})$ in ITS. Three strains of $O$. thailandicus differed by $0.4 \%$ (4/833 bp) in LSU and $2.8 \%$ (17/590 bp) in ITS. Two strains (MFLUCC 21-0112 and MFLU 21-0115) of O. pruinosellus differed by $1.9 \%$ (14/726 bp) in mtSSU. Two strains (MFLUCC 21-0113 and MFLU 21-0116) of O. thailandicus were completely identical within $713 \mathrm{bp}$ of mtSSU. Ostropomyces pruinosellus (MFLUCC 21-0112) and O. thailandicus (MFLUCC 21-0113) differed by 2.1\% (18/840 bp) in LSU, 8.1\% (46/567 bp) in ITS and $10 \%(77 / 706 \mathrm{bp})$ in $\mathrm{mtSSU}$. The low level of intraspecific diversity and higher interspecific diversity strongly suggests that $O$. pruinosellus and $O$. thailandicus are not conspecific.

Ostropomyces pruinosellus Thiyagaraja, Lücking, Ertz and K.D. Hyde, in Thiyagaraja, Lücking, Ertz, Karunarathna, Wanasinghe, Lumyong and Hyde, Journal of Fungi 7(no. 105): 12 (2021) Figure 4.

Index Fungorum number: IF 556556; Facesoffungi number: FoF 10097.

Saprobic on the dead stem of an unidentified climbing plant. Sexual morph: Ascomata 230-300 × 300-365 $\mu \mathrm{m}(\overline{\mathrm{x}}=265 \times 330, n=5)$, perithecial, subglobose, unilocular, gregarious, immersed at first and raising the substrates into small pustules and later opening by entire pores, exposing the discs. Discs pale grey to olivaceous, convex and covered by thick pruinose substance. Inner mass creamy-yellow. Exciple 25-50 $\mu \mathrm{m}(\overline{\mathrm{x}}=40, n=20)$, comprising interwoven and hyaline hyphae without crystalline inclusions and periphysoidal layers. Hymenium consisted of paraphyses and asci, lying parallel to the substrates. Paraphyses 1-3 $\mu \mathrm{m}(\overline{\mathrm{x}}=2, n=30)$ wide, anastomosing, aseptate, branched and longer than asci. Asci 180-265 × 9-15 $\mu \mathrm{m}(\overline{\mathrm{x}}=220 \times 12, \mathrm{n}=20)$, cylindrical, unitunicate and thick-walled, with a thickened cap. Apical caps 5-6.5 $\times 3-4.5 \mu \mathrm{m}(\overline{\mathrm{x}}=5.5 \times 3.7, n=5)$, hemispheric and pierced by a pore. Ascospores hyaline, filiform, as long as asci and easily disarticulating into part-spores in mature asci. Part-spores 2.5-6 $\times 2-3 \mu \mathrm{m}(\overline{\mathrm{x}}=4 \times 2.5, n=40)$, subglobose to ellipsoidal and unicellular, with two oil droplets. Asexual morph: Undetermined. 

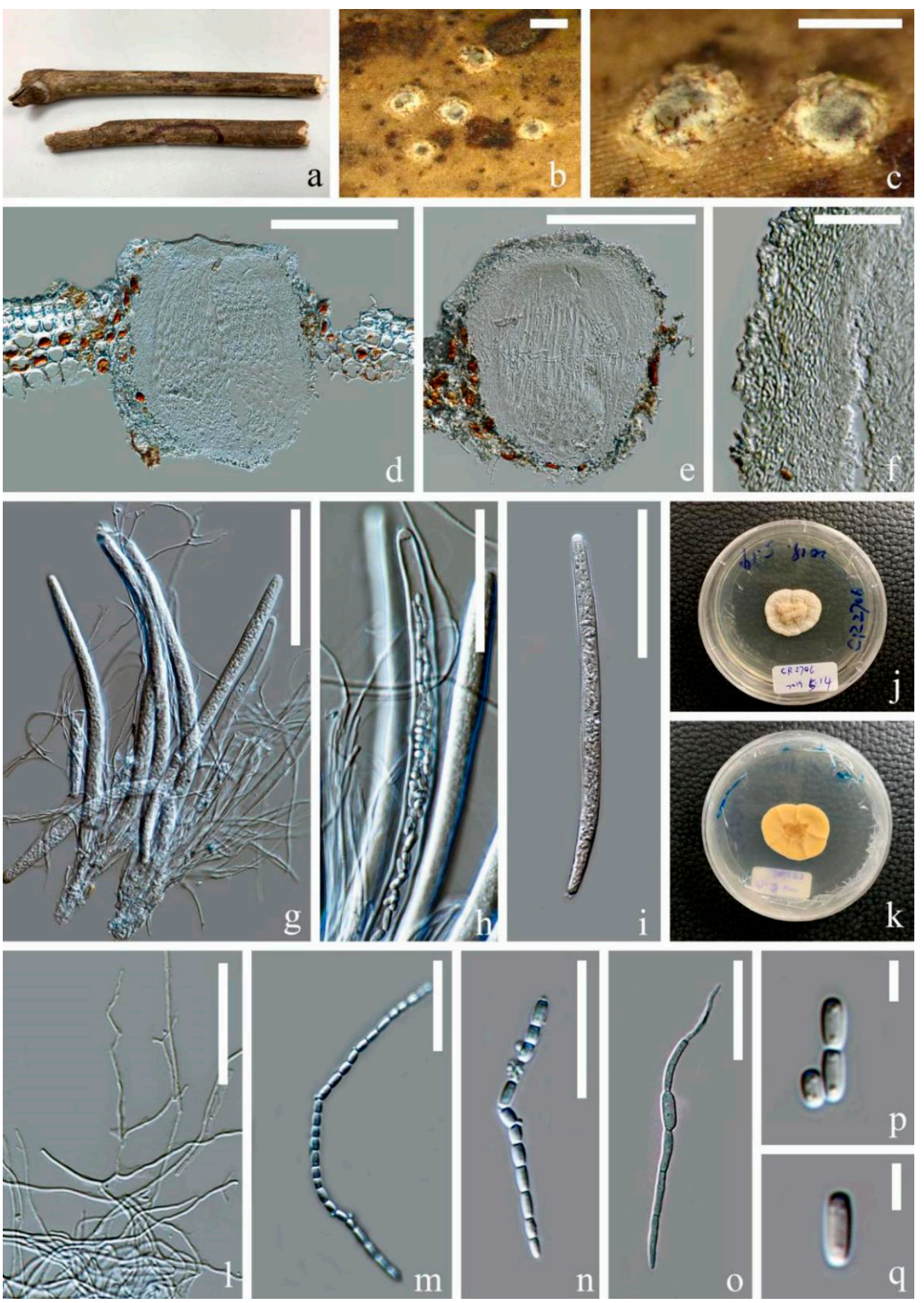

Figure 4. Ostropomyces pruinosellus (MFLU 21-0115). (a) Substrate; (b,c) ascomata on host; (d,e) vertical sections through ascomata; (f) excipulum; (g-i) Asci; (j,k) upper and lower view of culture on PDA media after incubation for two months; (1) paraphyses; $(\mathbf{m}, \mathbf{n})$ catenulate ascospores; (o) germinating ascospore; (p,q) part-spores. Scale bars: $(\mathbf{b}, \mathbf{c})=500 \mu \mathrm{m} ;(\mathbf{d}, \mathbf{e})=200 \mu \mathrm{m} ;(\mathbf{g}, \mathbf{i})=100 \mu \mathrm{m}$; $(\mathbf{h}, \mathbf{l})=50 \mu \mathrm{m} ;(\mathbf{f}, \mathbf{m}-\mathbf{o})=30 \mu \mathrm{m} ;(\mathbf{p}, \mathbf{q})=5 \mu \mathrm{m}$.

Culture characters: Culture was established from germinating part-spores. The colony was slowly grown on PDA media, reaching $3 \mathrm{~cm}$ after incubation for two months in $28^{\circ} \mathrm{C}$. It was sterile, yellowish white, nearly circular, dense, umbonate, surface folded, cottony and reverse creamy-yellow. 
Material examined: Thailand, Chiang Rai Province, Doilan District, on dead stem of an unidentified dicotyledonous climbing plant, 27 March 2019, Deping Wei, CR2706 (MFLU 21-0115); living culture MFLUCC 21-0112.

Notes: Our isolate (MFLU 21-0115) resembles Ostropomyces pruinosellus (MFLU 200539) in having subglobose, white-pruinose, perithecioid ascomata, cylindrical asci and filamentous, anastomosing paraphyses and filiform ascospores that disarticulate into numerous ellipsoidal part-spores. Phylogenetic analyses supported close affinity of our isolates (MFLU 21-0115 and MFLUCC 21-0112) to Ostropomyces pruinosellus (MFLU 200538), and the three were grouped together with maximum statistical support. Here, we consider our isolate as a new collection of Ostropomyces pruinosellus and provide additional molecular and morphological data as well as culture characteristics for this species.

Ostropomyces thailandicus Thiyagaraja, Lücking, Ertz and K.D. Hyde, in Thiyagaraja, Lücking, Ertz, Karunarathna, Wanasinghe, Lumyong and Hyde, Journal of Fungi 7(no. 105): 13 (2021) Figure 5.

Index Fungorum number: IF 556557; Facesoffungi number: FoF 10098.

Saprobic on dead stem of an unidentified climbing plant. Asexual morph: Conidiomata 100-300 × 100-200 $\mathrm{mm}(\overline{\mathrm{x}}=200 \times 150, n=10)$, pycnidial, gregarious, completely immersed to erumpent, unilocular, ostiolate, with irregularly branched and confluent basal parts, showing variously shapes ranging from globose and flask-shaped to cordiform in the vertical section. They contained dark inner content visible with black dots on the host surface. The host epidermis around the conidiomata is white. Conidiomatal wall 10-20 $\mu \mathrm{m}$ $(\bar{x}=15, n=25)$, consisted of hyaline and interwoven hyphae without crystalline inclusions. Conidiophores reduced to conidiogenous cells. Conidiogenous cells $2-6 \times 1-3 \mu \mathrm{m}$ $(\bar{x}=4 \times 2, n=50)$, arising from inner layer of the cavity, sub-cylindrical to ampulliform, hyaline, smooth-walled cell and monoblastic. Conidia 7.5-13 $\times 1.5-3 \mu \mathrm{m}(\overline{\mathrm{x}}=10 \times 2$, $n=40$ ), hyaline, ellipsoidal and unicellular, with minute oil droplets. They are percurrently proliferating and produced in unbranched chains.

Culture characteristics: Culture was established from the germinating conidia. Colony slowly growing on PDA media, attaining $2 \mathrm{~cm}$ after incubation for two months in $28^{\circ} \mathrm{C}$. The culture was sterile, yellowish white, nearly circular, dense, raised, surface folded, cottony and reverse creamy-yellow. It produced yellow-white and dispersive crystal substances in agar.

Material examined: Thailand, Chiang Rai Province, Doilan District, on the dead stem of an unidentified dicotyledonous climbing plant, 27 March 2019, Deping Wei, CR2708 (MFLU 21-0116); living culture MFLUCC 21-0113.

Notes: In the ITS, LSU and mtSSU combined phylogenetic analysis, our strains MFLUCC 21-0113 and MFLU 21-0116 formed a clade with Ostropomyces thailandicus (MFLU 20-0539) with 100 MLBS/1.00 PP statistical support values (Figure 2). The MFLU 21-0116 isolate shares similar morphological characteristics to the type specimen (MFLU 20-0539) in having irregular-shaped conidiomata, hyaline, cylindrical conidiogenous cells and catenulate conidia that easily break into small, numerous and ellipsoidal units (Figure 4). Therefore, we introduced our isolate MFLU 21-0116 as a new collection of O. thailandicus. This species produces many crystal-like substances on PDA in vitro, which has rarely been reported in known Stictidaceae species. Additionally, based on the collections in this study and Thiyagaraja et al. [20], we found that O. thailandicus and O. pruinosellus likely occurred in close proximity to each other. 

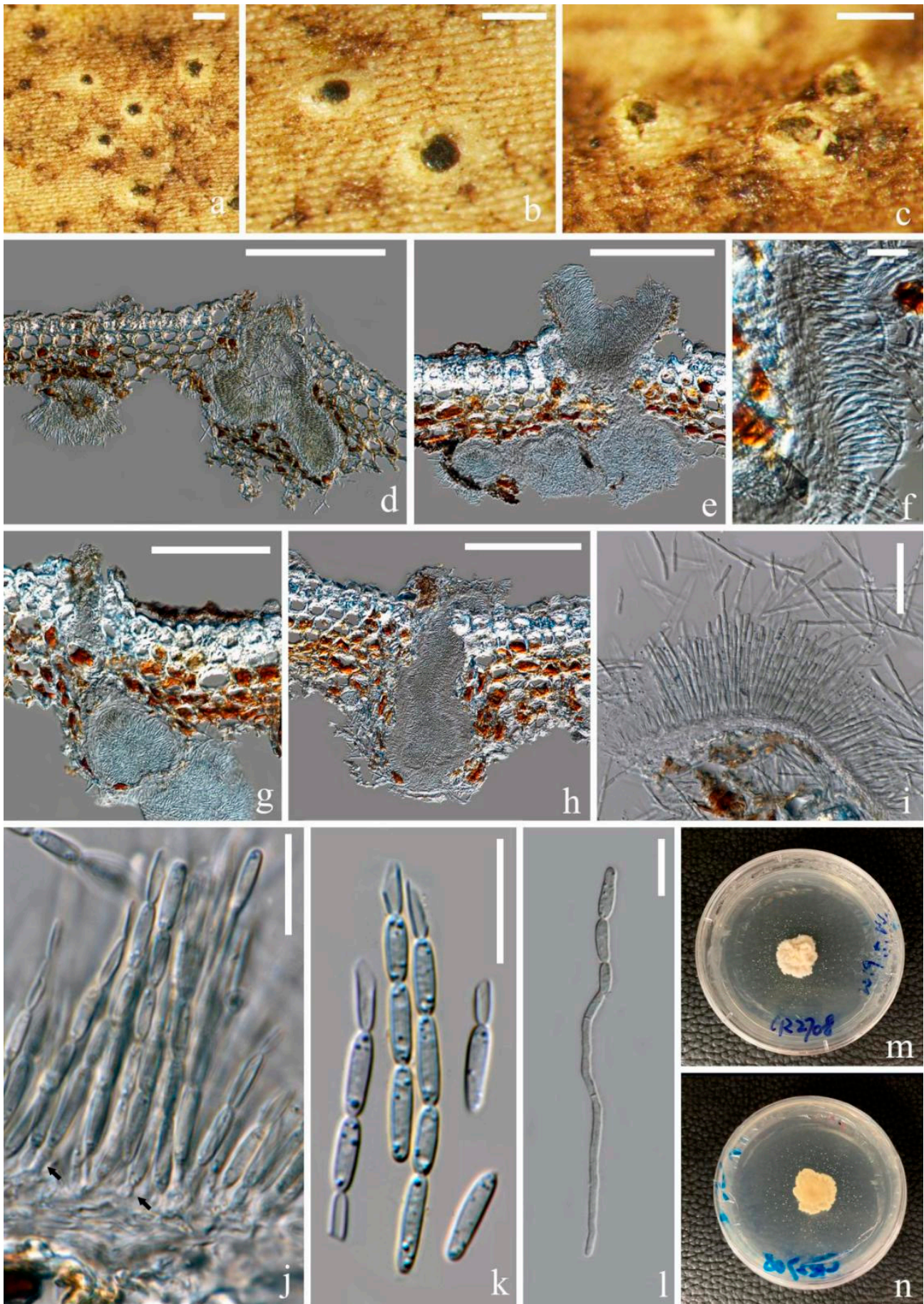

Figure 5. Ostropomyces thailandicus (MFLU 21-0116) (a-c) Conidiomata on host; (d,e,g,h) vertical sections through conidiomata; (f) conidiomatal wall; $(\mathbf{i}, \mathbf{j})$ conidiogenous cells (indicated with black arrows); (k) conidia; (l) germinal conidia; $(\mathbf{m}, \mathbf{n})$ upper and lower view of culture on PDA media after incubation for two months. Scale bars: $(\mathbf{a}-\mathbf{d})=200 \mu \mathrm{m} ;(\mathbf{e}, \mathbf{g}, \mathbf{h})=150 \mu \mathrm{m} ;(\mathbf{i})=50 \mu \mathrm{m} ;(\mathbf{f}, \mathbf{j}-\mathbf{l})=15 \mu \mathrm{m}$.

\section{Discussion}

It has been previously hypothesized that the common ancestor of Ostropales was lichenized and that the extant saprotrophic lineages are the result of multiple losses of lichenization [2,72]. Thiyagaraja et al. [20] also proposed that Stictidaceae was derived from loss of lichenization. In the phylogenetic analysis herein, we manually mapped lifestyles on the phylogenetic tree (Figure 2). Information on species lifestyles was acquired from relevant references $[2,26]$. Taxa included in the phylogenetic analysis herein comprised five 
lifestyles: (1) saprotrophic, (2) lichenized, (3) optionally lichenized, (4) lichenicolous and (5) endophytic. The present phylogenetic tree shows that saprobes are broadly dispersed throughout the tree; lichenized species disperse in six clades, optionally lichenized in three, lichenicolous in two and endophytic in one. The high diversity of life modes is notable even within genera; for example, within Cryptodiscus three lifestyles are present, while there are two within Sphaeropezia and Stictis. Collective consideration of previous findings and those herein supports the conclusions of Thiyagaraja et al. [20] regarding the saprobic nature of the common ancestor of Stictidaceae and the convergent development of non-saprobic life modes in this family. One, however, cannot draw firm conclusions at this point as 10 genera lack molecular data; thus, their phylogenetic position within Stictidaceae is undetermined. Notably some of these genera are parasitic, and it would be of interest to see their distribution across the tree. Regardless, the observed notable plasticity of lifestyles might represent a strategy of fungi adapted to habitats, where succession commonly occurs [55] and a driving force facilitating speciation in Stictidaceae [20].

In this study, we used sequences from 22 of the 32 genera in Stictidaceae to infer the phylogeny of this family (see Figure 2). Of these 22 genera, more than two taxa were sampled from Cryptodiscus, Cyanodermella, Fitzroyomyces, Sphaeropezia, Schizoxylon and Stictis, while this was not possible for the other 16 genera due to the lack of molecular data. The Cryptodiscus clade has maximum statistical support and comprises nine species, most of which have few-celled ascospores. These include Cryptodiscus cladoniicola (cylindrical to slightly fusiform, (2-)3(-4)-septate) [33], C. epicladonia (filiform to cylindrical, (5-)7-11-septate) [33], C. foveolaris (oblong, 1-septate) [40], C. incolor (cylindrical-clavate, 3-5-septate) [27], C. gloeocapsa (cylindrical-fusiform, 3-4-septate) [40], C. muriformis (ellipsoid, muriform) [28], C. pallidus (fusiform, 3-septate) [40], C. pini (oblong, 1-septate) [40] and C. tabularum (cylindrical to cylindric-fusiform, 3-septate). Cryptodiscus epicladonia and C. muriformis are distinct within the genus in having filiform multiseptate ascospores and submuriform ascospores, respectively. The broad morphological diversity of the ascospore indicates that this character is not taxonomically significant for Cryptodiscus. The Fitzroyomyces clade contains three species, namely, Fitzroyomyces cyperacearum, F. hyaloseptisporus and F. pandanicola. All three species are similar in having long cylindrical ascospores with several prominent constrictions wherein the entire spore easily breaks into irregular fragments. The presence of these characters in all Fitzroyomyces species suggests that they might be useful diagnostic features of this genus. Sphaeropezia clade contains four species, including Sphaeropezia leucocheila (oblong-elliptic, 1-septate) [73], S. lyckselensis (cylindrical oblong, 3-septate) [42], S. mycoblasti (ellipsoidal, 3-septate) [42] and S. shangrilaensis (fusoid to obovoid, aseptate) [20]. The four species form short, nearly cylindrical and few-celled (0-3-septate) ascospores, indicating that the ascospore morphology is consistent and is, thus, a phylogenetically informative character within Sphaeropezia. Five Stictis species with filiform, multiseptated and non-disarticulating ascospores are included in our phylogenetic analyses forming at least four separate clades. Phylogenetic analyses in this and other studies suggest that Stictis should be subdivided into several genera [20]. Three Schizoxylon species were selected in the phylogenetic analysis herein. Schizoxylon gilenstamii and S. berkeleyanum formed a sister clade with high support, while S. albescens is sister to Glomerobolus gelineus with low support. In contrast to our findings, previous phylogenetic studies by Thiyagaraja et al. [20] and Fernández-Brime et al. [28] have recovered a monophyletic clade of Schizoxylon, albeit with weak support, implying that phylogenetic placement and membership of this genus remain unresolved. Additional studies and collections are necessary in order to figure out the phylogenetically informative characters at the species and genus level within Stictidaceae.

Of the ten genera that lack molecular data, Conotremopsis, Delpontia and Propoliopsis are monotypic. Conotremopsis is distinct in having superficial, elongated and keeve-like apothecia [34]. Delpontia has submuriform ascospores similar to those in Cryptodiscus and Topelia. Nonetheless, Delpontia can be easily distinguished from Topelia. The former forms wide-opening apothecia and has a non-lichenized lifestyle, while the latter has closed 
perithecioid apothecia and a lichenized lifestyle $[13,43]$. Cryptodiscus is diverse in terms of ascospore character morphology, apothecia nature and lifestyle $[13,27,28]$, which can result in confusion as to its relationship with Delpontia. The other genera lacking molecular data are not monotypic. Dendroseptoria is distinct in its sporodochial fruiting bodies and staurosporous conidia [48], while Stictophacidium is set apart in having unicellular ascospores [13]. Biostictis, Karstenia, Lillicoa and Nanostictis have long clavate, cylindrical to filiform and multiseptate ascospores that resemble those of the majority of species in Stictis and Schizoxylon [13,35]. When taking shape and septation of ascospores into consideration, there is no clear-cut boundary among these eight genera. However, they can be distinguished based on other features. For instance, all members of Biostictis are reported as parasites of living leaves of plants [13]. Karstenia is unique in that it forms covering layers that consist of short-celled, vertically oriented hyphae ending in a fringe of hair-like projections [13]. All members of Lillicoa inhabit living leaves and seemingly are not lichenized. Conversely, all members of Nanostictis are obligately lichenicolous [13]. Hence, features such as lifestyle, substrate preference, nature of apothecia/conidiomata, structure of exciple and ascospore/conidia morphology are of taxonomic significance either independently or in combination for specific taxa. Molecular data are needed to examine the value of these diagnostic characters in intrageneric and intergeneric classification.

Sexual-asexual connections have been established for only a few genera of Stictidaceae including Stictis and Acarosporina using cultures and molecular evidence [28,52,53]. In Schizoxylon pseudocyanosporum, the asexual conidiomata were linked to its sexual apothecia solely on the basis of their close proximity to each other $[13,53]$. The connection, however, has not been confirmed by using pure cultures or molecular data. Similarly, this study and Thiyagaraja et al. [20] reported the intermingled occurrence of both sexual and asexual morphs together on the same substrate. Although it could be speculated that the two morphs belong to the same species, this is not very likely. Molecular data derived from pure cultures and subsequent sequence and phylogenetic analyses (see notes, Figure 2) collectively suggest that the two morphs are in fact separate species. In the phylogenetic analysis, the sexual morph grouped with Ostropomyces pruinosellus, while the asexual morph clustered with $O$. thailandicus. Moreover, the interspecific genetic diversity of all genetic markers used in this study between O. pruinosellus and O. thailandicus clearly indicates that the two are not conspecifics. Thus, establishing sexual-asexual links should not be based solely on the close proximity of the two morphs, as in the case of S. pseudocyanosporum, but supplemented with molecular data.

In this study, we have explored the taxonomic significance of characters for Stictidaceae. However, limited taxa sampling in the phylogenetic analyses hinders us from drawing a firm conclusion on this point. Additionally, taxonomic placements of pathogenic/parasitic species in Stictidaceae are as yet unclear due to the lack of molecular data. It would be interesting to observe if the addition of these taxa will confirm the saprobic nature of the ancestor of this family. Stictis contains many species, which were introduced solely on the basis of morphological observation, so gaps remain in terms of its natural classification using moleculebased phylogeny. Therefore, additional collections especially of early branching and undersampled species are urgently needed in the future to address the issues mentioned above.

Author Contributions: Conceptualization, D.-P.W., D.N.W. and E.G.; methodology, D.-P.W., E.G., D.N.W. and V.T.; software, D.-P.W., D.N.W. and E.G.; validation, E.G., S.L. and K.D.H.; formal analysis, D.-P.W., D.N.W. and E.G.; investigation, D.-P.W., D.N.W. and E.G.; resources, D.-P.W. and E.G.; data curation, D.-P.W.; writing-original draft preparation, D.-P.W.; writing-review and editing, E.G., D.N.W. and K.D.H.; visualization, D.N.W. and E.G.; supervision, D.N.W., E.G. and K.D.H.; project administration, K.D.H.; funding acquisition, K.D.H. All authors have read and agreed to the published version of the manuscript.

Funding: This research was found by National Natural Science Foundation of China (NNSFC), grant number 31861143002, titled "Characterization of roots and their associated rhizosphere microbes in agroforestry systems: ecological restoration in high-phosphorus environment". 
Institutional Review Board Statement: Not applicable.

Informed Consent Statement: Not applicable.

Data Availability Statement: Not applicable.

Acknowledgments: We thank Kunming Institute of Botany for providing the laboratories and instruments for molecular work. We thank National Natural Science Foundation of China (NNSFC), grant number 31861143002, titled "Characterization of roots and their associated rhizosphere microbes in agroforestry systems: ecological restoration in high-phosphorus environment" for its financial support. We also thank the Centre of Excellence in Fungal Research (Mae Fah Luang University) for providing funding for collecting trips. We are grateful for the National Science Foundation of China (NSFC), project code 31750110478, for funding the sequencing cost. We acknowledge Thailand Research Fund (TRF), grant no. DBG6080013, titled "The future of specialist fungi in a changing climate: baseline data for generalist and specialist fungi associated with ants, Rhododendron species and Dracaena species" for the materials used for experiments. The Thailand Science Research and Innovation (TSRI) grant titled "Macrofungi diversity research from the Lancang-Mekong Watershed and Surrounding areas (grant no. DBG6280009)" is thanked for supporting the collection trip. K.D. Hyde thanks Chiang Mai University for the award of Visiting Professor. Dhanushka N. Wanasinghe would like to thank CAS President's International Fellowship Initiative (PIFI) for funding his postdoctoral research (number 2021FYB0005 and the Postdoctoral Fund from Human Resources and Social Security Bureau of Yunnan Province for financial support. Jutamart Monkai is thanked for organizing the collection trip, and Guang-Cong Ren is thanked for his help on sequencing the specimens.

Conflicts of Interest: The authors declare no conflict of interest.

\section{References}

1. Nannfeldt, J.A. Studien iiber die Morphologie und Systematik der nichtlichenisierten inoperculaten Discomyceten. Nov. Acta Regiae Soc. Sci. Upsal. 1932, 8, 1-368.

2. Baloch, E.; Lücking, R.; Lumbsch, H.T.; Wedin, M. Major clades and phylogenetic relationships between lichenized and nonlichenized lineages in Ostropales (Ascomycota: Lecanoromycetes). Taxon 2010, 59, 1483-1494. [CrossRef]

3. Lumbsch, H.T.; Schmitt, I.; Lücking, R.; Wiklund, E.; Wedin, M. The phylogenetic placement of Ostropales within Lecanoromycetes (Ascomycota) revisited. Mycol. Res. 2007, 111, 257-267. [CrossRef] [PubMed]

4. Wijayawardene, N.N.; Hyde, K.D.; Al-Ani, L.K.T.; Tedersoo, L.; Haelewaters, D.; Rajeshkumar, K.C.; Zhao, R.L.; Aptroot, A.; Leontyev, D.; Saxena, R.K.; et al. Outline of Fungi and fungus-like taxa. Mycosphere 2020, 11, 1060-1456. [CrossRef]

5. Wijayawardene, N.N.; Hyde, K.D.; Lumbsch, H.T.; Liu, J.K.; Maharachchikumbura, S.S.N.; Ekanayaka, A.H.; Tian, Q.; Phookamsak, R. Outline of Ascomycota: 2017. Fungal Divers. 2018, 88, 167-263. [CrossRef]

6. Lumbsch, H.T.; Huhndorf, S.M. Outline of Ascomycota-2009. Myconet 2010, 14, 1-64.

7. Lumbsch, H.T.; Huhndorf, S.M. Outline of Ascomycota-2007. Myconet 2007, 13, 1-58.

8. Nelsen, M.P.; Lücking, R.; Andrew, C.J.; Aptroot, A.; Cáceres, M.E.S.; Mercado-Díaz, J.A.; Plata, E.R.; Lumbsch, H.T. Molecular phylogeny reveals the true colours of Myeloconidaceae (Ascomycota: Ostropales). Aust. Syst. Bot. 2014, 27, 38-47. [CrossRef]

9. Kraichak, E.; Huang, J.-P.; Nelsen, M.; Leavitt, S.D.; Lumbsch, H.T. A revised classification of orders and families in the two major subclasses of Lecanoromycetes (Ascomycota) based on a temporal approach. Bot. J. Linn. Soc. 2018, 188, 233-249. [CrossRef]

10. Lücking, R. Stop the abuse of time! Strict temporal banding is not the future of rank-based classifications in fungi (including lichens) and other organisms. CRC. Crit. Rev. Plant Sci. 2019, 38, 199-253. [CrossRef]

11. Fries, E.M. Summa Vegetabilium Scandinaviae; Bonnier: Winter Park, FL, USA, 1849; Volume 2, pp. $259-572$.

12. Winka, K.; Ahlberg, C.; Eriksson, O.E. Are there lichenized Ostropales? Lichenologist 1998, 30, 455-462. [CrossRef]

13. Sherwood, M.A. The ostropalean fungi. Mycotaxon 1977, 5, 1-277.

14. Sherwood, M.A. The Ostropalean fungi II: Schizoxylon with notes on Stictis, Acarosporina, Coccopeziza, and Carestiella. Mycotaxon 1977, 6, 215-260.

15. Crous, P.W.; Wingfield, M.J.; Burgess, T.I.; Hardy, G.; Gené, J.; Guarro, J.; Baseia, I.G.; García, D.; Gusmão, L.; Souza-Motta, C.M.; et al. Fungal Planet description sheets: 716-784. Persoonia 2018, 40, 240-393. [CrossRef]

16. Crous, P.W.; Wingfield, M.J.; Chooi, Y.-H.; Gilchrist, C.L.M.; Lacey, E.; Pitt, J.I.; Roets, F.; Swart, W.J.; Cano-Lira, J.F.; ValenzuelaLopez, N.; et al. Fungal Planet description sheets: 1042-1111. Persoonia 2020, 44, 301-459. [CrossRef]

17. Crous, P.W.; Schumacher, R.K.; Wood, A.R.; Groenewald, J.Z. The Genera of Fungi-G5: Arthrinium, Ceratosphaeria, Dimerosporiopsis, Hormodochis, Lecanostictopsis, Lembosina, Neomelanconium, Phragmotrichum, Pseudomelanconium, Rutola, and Trullula. Fungal Syst. Evol. 2020, 5, 77-98. [CrossRef]

18. Aptroot, A.; Parnmen, S.; Luecking, R.; Baloch, E.; Jungbluth, P.; Caceres, M.E.S.; Lumbsch, H.T. Molecular phylogeny resolves a taxonomic misunderstanding and places Geisleria close to Absconditella s. str.(Ostropales: Stictidaceae). Lichenologist 2014, 46, 115-128. [CrossRef] 
19. Kohlmeyer, J.; Volkmann-Kohlmeyer, B. Fungi on Juncus roemerianus. 6. Glomerobolus gen. nov., the first ballistic member of Agonomycetales. Mycologia 1996, 88, 328-337.

20. Thiyagaraja, V.; Lücking, R.; Ertz, D.; Karunarathna, S.C.; Wanasinghe, D.N.; Lumyong, S.; Hyde, K.D. The evolution of life modes in Stictidaceae, with three novel taxa. J. Fungi 2021, 7, 105. [CrossRef]

21. Ertz, D.; Sanderson, N.; Lebouvier, M. Thelopsis challenges the generic circumscription in the Gyalectaceae and brings new insights to the taxonomy of Ramonia. Lichenologist 2021, 53, 45-61. [CrossRef]

22. Schoch, C.L.; Kohlmeyer, J.; Volkmann-Kohlmeyer, B.; Tsui, C.K.M.; Spatafora, J.W. The halotolerant fungus Glomerobolus gelineus is a member of the Ostropales. Mycol. Res. 2006, 110, 257-263. [CrossRef] [PubMed]

23. Crous, P.W.; Luangsa-Ard, J.J.; Wingfield, M.J.; Carnegie, A.J.; Hernández-Restrepo, M.; Lombard, L.; Roux, J.; Barreto, R.W.; Baseia, I.G.; Cano-Lira, J.F.; et al. Fungal Planet description sheets: 785-867. Persoonia 2018, 41, 238-417. [CrossRef]

24. Crous, P.W.; Wingfield, M.J.; Schumacher, R.K.; Akulov, A.; Bulgakov, T.S.; Carnegie, A.J.; Jurjević, Ž.; Decock, C.; Denman, S.; Lombard, L.; et al. New and Interesting Fungi. 3. Fungal Syst. Evol. 2020, 6, 157-231. [CrossRef] [PubMed]

25. Tibpromma, S.; Hyde, K.D.; McKenzie, E.H.C.; Bhat, D.J.; Phillips, A.J.L.; Wanasinghe, D.N.; Samarakoon, M.C.; Jayawardena, R.S.; Dissanayake, A.J.; Tennakoon, D.S.; et al. Fungal diversity notes 840-928: Micro-fungi associated with Pandanaceae. Fungal Divers. 2018, 93, 1-160.

26. Wedin, M.; Döring, H.; Koenberg, K.; Gilenstam, G. Generic delimitations in the family Stictidaceae (Ostropales, Ascomycota): The Stictis-Conotrema problem. Lichenologist 2005, 37, 67-75. [CrossRef]

27. Baloch, E.; Gilenstam, G.; Wedin, M. Phylogeny and classification of Cryptodiscus, with a taxonomic synopsis of the Swedish species. Fungal Divers. 2009, 38, 51-68.

28. Fernández-Brime, S.; Olariaga, I.; Baral, H.-O.; Friebes, G.; Jaklitsch, W.; Senn-Irlet, B.; Wedin, M. Cryptodiscus muriformis and Schizoxylon gilenstamii, two new species of Stictidaceae (Ascomycota). Mycol. Prog. 2018, 17, 295-305. [CrossRef]

29. Yang, C.L.; Baral, H.-O.; Xu, X.; Liu, Y. Parakarstenia phyllostachydis, a new genus and species of non-lichenized Odontotremataceae (Ostropales, Ascomycota). Mycol. Prog. 2019, 18, 833-845. [CrossRef]

30. Spribille, T.; Bjork, C.R. New records and range extensions in the North American lignicolous lichen flora. Mycotaxon 2008, 105, 455-468.

31. Halda, J.P.; Oh, S.-O.; Liu, D.; Lee, B.G.; Kondratyuk, S.Y.; Lőkös, L.; Park, J.-S.; Woo, J.-J.; Hur, J.-S. Two New Lichen Species, Thelopsis ullungdoensis and Phylloblastia gyeongsangbukensis from Korea. Mycobiology 2020, 48, 443-449. [CrossRef]

32. Van den Boom, P.; Brand, A.M.; Suija, A. A new species of Absconditella from western and central Europe with a key to the European members. Phytotaxa 2015, 238, 271-277. [CrossRef]

33. Pino-Bodas, R.; Zhurbenko, M.P.; Stenroos, S. Phylogenetic placement within Lecanoromycetes of lichenicolous fungi associated with Cladonia and some other genera. Persoonia 2017, 39, 91-117. [CrossRef]

34. Vězda, A. Flechtensystematische Studien X. Conotremopsis weberiana gen. novum et sp. nova, eine neue Flechte aus der Familie Ostropaceae. Folia Geobot. Phytotaxon. 1977, 12, 313-316.

35. Sherwood, M.A. New Ostropales from the collections of the Farlow Herbarium. Occas. Pap. Farlow Herb. Cryptogam. Bot. 1978, 13, 39-47. [CrossRef]

36. Phukhamsakda, C.; McKenzie, E.H.C.; Phillips, A.J.L.; Jones, E.B.G.; Bhat, D.J.; Stadler, M.; Bhunjun, C.S.; Wanasinghe, D.N.; Thongbai, B.; Camporesi, E.; et al. Microfungi associated with Clematis (Ranunculaceae) with an integrated approach to delimiting species boundaries. Fungal Divers. 2020, 102, 1-203. [CrossRef]

37. Ekanayaka, A.H.; Hyde, K.D.; Jones, E.B.G.; Zhao, Q.; Bulgakov, T.S. New and known discolichens from Asia and eastern Europe. Asian J. Mycol. 2019, 2, 48-86. [CrossRef]

38. Kantvilas, G. Two ephemeral species of the lichen genus Absconditella (Stictidaceae) new to Tasmania. Muelleria 2005, 21, 91-95.

39. Kalb, K.; Aptroot, A. New lichen species from Brazil and Venezuela. Bryologist 2018, 121, 56-66. [CrossRef]

40. Baloch, E.; Döring, H.; Spooner, B.M. The Genus Cryptodiscus in Great Britain. Field Mycol. 2010, 11, 26-32. [CrossRef]

41. Hjortstam, K.; Ramos Bononi, V.L. A contribution to the knowledge of Corticiaceae sl (Aphyllophorales) in Brazil. Mycotaxon 1987, 28, 1-15.

42. Baloch, E.; Gilenstam, G.; Wedin, M. The relationships of Odontotrema (Odontotremataceae) and the resurrected Sphaeropezia (Stictidaceae)—New combinations and three new Sphaeropezia species. Mycologia 2013, 105, 384-397. [CrossRef] [PubMed]

43. Aptroot, A.; de Oliveira, M.C.; Ferraro, L.I.; Cáceres, M.E.S. A world key to species of the genera Topelia and Thelopsis (Stictidaceae), with the description of three new species from Brazil and Argentina. Lichenologist 2014, 46, 801-807. [CrossRef]

44. Kalb, J.; Kalb, K. New lichen species from Thailand, new combinations and new additions to the Thai lichen biota. Phytotaxa 2017, 332, 141-156. [CrossRef]

45. Lücking, R.; Rivas Plata, E.; Mangold, A.; Sipman, H.J.M.; Aptroot, A.; Miranda González, R.; Kalb, K.; Chaves, J.L.; Ventura, N.; EsmeraldaEsquivel, R. Natural history of Nash's Pore Lichens, Trinathotrema (Ascomycota: Lecanoromycetes: Ostropales: Stictidaceae). Bibl. Lichenol. 2011, 106, 183-206.

46. Fernández-Brime, S.; Llimona, X.; Molnar, K.; Stenroos, S.; Hognabba, F.; Bjork, C.; Lutzoni, F.; Gaya, E. Expansion of the Stictidaceae by the addition of the saxicolous lichen-forming genus Ingvariella. Mycologia 2011, 103, 755-763. [CrossRef]

47. Nylander, W. Addenda nova ad Lichenographiam Europaeam. Continuatio septima. Flora 1868, 51, 161-165.

48. Koukol, O.; Hofmann, T.A.; Piepenbring, M. Dendroseptoria mucilaginosa: A new anamorphic fungus with stauroconidia and phylogenetic placement of Dendroseptoria. Mycol. Prog. 2017, 16, 1065-1070. [CrossRef] 
49. Crous, P.W.; Wingfield, M.J.; Schumacher, R.K.; Summerell, B.A.; Giraldo, A.; Gené, J.; Guarro, J.; Wanasinghe, D.N.; Hyde, K.D.; Camporesi, E.; et al. Fungal Planet description sheets: 281-319. Persoonia 2014, 33, 212-289. [CrossRef]

50. Crous, P.W.; Wingfield, M.J.; Burgess, T.I.; Carnegie, A.J.; Hardy, G.E.S.J.; Smith, D.; Summerell, B.A.; Cano-Lira, J.F.; Guarro, J.; Houbraken, J.; et al. Fungal Planet description sheets: 625-715. Persoonia 2017, 39, 270-467. [CrossRef]

51. Van Nieuwenhuijzen, E.J.; Miadlikowska, J.M.; Houbraken, J.A.M.P.; Adan, O.C.G.; Lutzoni, F.M.; Samson, R.A. Wood staining fungi revealed taxonomic novelties in Pezizomycotina: New order Superstratomycetales and new species Cyanodermella oleoligni. Stud. Mycol. 2016, 85, 107-124. [CrossRef]

52. Johnston, P.R. Stictis and its anamorphs in New Zealand. N.Z. J. Bot. 1983, 21, 249-279. [CrossRef]

53. Johnston, P.R. Anamorphs of the ostropalean genera Schizoxylon and Acarosporina. Mycotaxon 1985, 24, 349-360.

54. Diederich, P.; Lawrey, J.D.; Ertz, D. The 2018 classification and checklist of lichenicolous fungi, with 2000 non-lichenized, obligately lichenicolous taxa. Bryologist 2018, 121, 340-425. [CrossRef]

55. Wedin, M.; Döring, H.; Gilenstam, G. Saprotrophy and lichenization as options for the same fungal species on different substrata: Environmental plasticity and fungal lifestyles in the Stictis-Conotrema complex. New Phytol. 2004, 164, 459-465. [CrossRef]

56. Wedin, M.; Döring, H.; Gilenstam, G. Stictis s. lat. (Ostropales, Ascomycota) in northern Scandinavia, with a key and notes on morphological variation in relation to lifestyle. Mycol. Res. 2006, 110, 773-789. [CrossRef]

57. Senanayake, I.C.; Rathnayake, A.R.; Marasinghe, D.S.; Calabon, M.S.; Gentekaki, E.; Lee, H.B.; Hurdeal, V.G.; Pem, D.; Dissanayake, L.S.; Wijesinghe, S.N.; et al. Morphological approaches in studying fungi: Collection, examination, isolation, sporulation and preservation. Mycosphere 2020, 11, 2678-2754. [CrossRef]

58. Jayasiri, S.C.; Hyde, K.D.; Ariyawansa, H.A.; Bhat, J.; Buyck, B.; Cai, L.; Dai, Y.-C.; Abd-Elsalam, K.A.; Ertz, D.; Hidayat, I.; et al. The Faces of Fungi database: Fungal names linked with morphology, phylogeny and human impacts. Fungal Divers. 2015, 74, 3-18. [CrossRef]

59. Vilgalys, R.; Hester, M. Rapid genetic identification and mapping of enzymatically amplified ribosomal DNA from several Cryptococcus species. J. Bacteriol. 1990, 172, 4238-4246. [CrossRef] [PubMed]

60. White, T.J.; Bruns, T.; Lee, S.; Taylor, J. Amplification and direct sequencing of fungal ribosomal RNA genes for phylogenetics. a guide to methods and applications. PCR Protoc. Guide Methods Appl. 1990, 18, 315-322.

61. Zoller, S.; Scheidegger, C.; Sperisen, C. PCR primers for the amplification of mitochondrial small subunit ribosomal DNA of lichen-forming ascomycetes. Lichenologist 1999, 31, 511-516. [CrossRef]

62. Clewley, J.P. Macintosh sequence analysis software. Mol. Biotechnol. 1995, 3, 221-224. [CrossRef]

63. Katoh, K.; Standley, D.M. MAFFT multiple sequence alignment software version 7: Improvements in performance and usability. Mol. Biol. Evol. 2013, 30, 772-780. [CrossRef]

64. Sánchez, R.; Serra, F.; Tárraga, J.; Medina, I.; Carbonell, J.; Pulido, L.; de María, A.; Capella-Gutíerrez, S.; Huerta-Cepas, J.; Gabaldón, T.; et al. Phylemon 2.0: A suite of web-tools for molecular evolution, phylogenetics, phylogenomics and hypotheses testing. Nucleic Acids Res. 2011, 39, 470-474. [CrossRef]

65. Vaidya, G.; Lohman, D.J.; Meier, R. SequenceMatrix: Concatenation software for the fast assembly of multi-gene datasets with character set and codon information. Cladistics 2011, 27, 171-180. [CrossRef]

66. Miller, M.A.; Pfeiffer, W.; Schwartz, T. Creating the CIPRES Science Gateway for inference of large phylogenetic trees. In Proceedings of the 2010 Gateway Computing Environments Workshop (GCE), New Orleans, LA, USA, 14 November 2010; pp. 1-8.

67. Huelsenbeck, J.P.; Ronquist, F. MRBAYES: Bayesian inference of phylogenetic trees. Bioinformatics 2001, 17, 754-755. [CrossRef] [PubMed]

68. Rannala, B.; Yang, Z. Probability distribution of molecular evolutionary trees: A new method of phylogenetic inference. J. Mol. Evol. 1996, 43, 304-311. [CrossRef] [PubMed]

69. Zhaxybayeva, O.; Gogarten, J.P. Bootstrap, Bayesian probability and maximum likelihood mapping: Exploring new tools for comparative genome analyses. BMC Genom. 2002, 3, 4. [CrossRef] [PubMed]

70. Rambaut, A. FigTree v1. 4.0. A Graphical Viewer of Phylogenetic Trees. Available online: http://tree.bio.ed.ac.uk/software/ figtree/ (accessed on 1 August 2021).

71. Jeewon, R.; Hyde, K.D. Establishing species boundaries and new taxa among fungi: Recommendations to resolve taxonomic ambiguities. Mycosphere 2016, 7, 1669-1677. [CrossRef]

72. Lutzoni, F.; Pagel, M.; Reeb, V. Major fungal lineages are derived from lichen symbiotic ancestors. Nature 2001, 411, 937-940. [CrossRef]

73. Johnston, P.R.; Park, D.; Renner, M.A.M. Sphaeropezia leucocheila sp. nov. (Stictidaceae): A liverwort pathogen from New Zealand. Phytotaxa 2019, 409, 222-226. [CrossRef] 